\title{
KAP-1, a novel corepressor for the highly conserved KRAB repression domain
}

\author{
Josh R. Friedman, ${ }^{1}$ William J. Fredericks, ${ }^{1}$ David E. Jensen,, ${ }^{1}$ David W. Speicher, ${ }^{1}$ Xiao-Pei Huang, \\ Eric G. Neilson, ${ }^{2}$ and Frank J. Rauscher III ${ }^{1,3}$ \\ ${ }^{1}$ The Wistar Institute, Philadelphia, Pennsylvania 19104 USA; $^{2}$ The University of Pennsylvania School of Medicine, \\ Philadelphia, Pennsylvania 19104 USA
}

The KRAB repression domain is one of the most widely distributed transcriptional effector domains yet identified, but its mechanism of repression is unknown. We have cloned a corepressor, KAP-1, which associates with the KRAB domain but not with KRAB mutants that have lost repression activity. KAP-1 can enhance KRAB-mediated repression and is a repressor when directly tethered to DNA. KAP-1 contains a RING finger, B boxes, and a PHD finger; the RING-B1-B2 structure is required for KRAB binding and corepression. We propose that KAP-1 may be a universal corepressor for the large family of KRAB domain-containing transcription factors.

[Key Words: Corepressor; RING finger; KRAB domain; zinc-finger]

Received April 23, 1996; revised version accepted July 9, 1996.

Transcriptional regulation of gene expression is mediated primarily by DNA sequence-specific transcription factors, which are generally composed of a DNA-binding domain and one or more separable effector domains that may activate or repress transcriptional initiation (for review, see Tjian and Maniatis 1994; Zawcl and Reinberg 1995). Activation domains may function by directly interacting with components of the basal transcriptional machinery, thereby nucleating, stabilizing, and/or facilitating the assembly and initiation of the RNA pol Il transcription complex. Alternatively, activation domains may function through a novel class of intermediary molecules variously termed adaptors or coactivators (for review, see Guarente 1995). These intermediary molecules must be tethered to the DNA template via protein-protein interactions with the effector domain of the DNA-bound transcription factor, thus serving to bridge the activation domain to the ultimate downstream target.

In contrast to our knowledge of activators, less is known regarding the mechanisms utilized by repression domains. Not surprisingly, repression domains may contact components of the basal transcription machinery (Fondell et al. 1993, 1996; Baniahmad et al. 1995; Sauer et al. 1995; Um et al. 1995/ or molecules with propertics suggestive of corepressor function. Emerging models of repressor--corepressor interaction include hairy-groucho in Drosophila (Paroush et al. 1994; Fisher et al. 1996), SSN6/TUP1-MCM1/MATa2 in yeast (Keleher et al. 1992; Cooper et al. 1994; Tzamarias and Struhl 19941, MAD/MAX-mSIN-3 in mammalian cells (Ayer et al.

${ }^{3}$ Corresponding author.
1995; Schreiber-Agus et al. 19951, and N-CoR or SMRT interaction with the nuclear hormone receptor family (Chen and Evans 1995; Horlein ct al. 1995). A common theme among these examples is that mutations in the DNA-bound repression domain that abolish interaction with the corepressor molecule also eliminate the repression function.

The KRAB (Krüppel-associated box) is a repression domain (Fig. 1) that is encoded by many transcription factors. It was originally identified in humans as a conserved amino acid sequence motif at the amino termini of proteins that contain multiple TFIIA/Krüppel-class $\mathrm{Cys}_{2}-\mathrm{His}_{2}\left(\mathrm{C}_{2} \mathrm{H}_{2}\right\}$ zinc fingers in their carboxyl termini (Bellefroid et al. 1991). The KRAB domain has now been identified in frog, rodent, and human zinc-finger proteins Altaba et al. 1987; Thiesen et al. 1991; ConstantinouDeltas et al. 1992; Witzgall et al. 1994; Vissing et al. 1995). Betwecn 300 and 700 human genes encode $\mathrm{C}_{2} \mathrm{H}_{2}$ zinc-finger proteins (Klug and Schwabe 1995), and onethird of these contain KRAB domains (Bellefroid et al. 1991). To date $\sim 65$ unique KRAB domain sequences have been isolated. The KRAB domain homology (Fig. 1) consists of $\sim 75$ amino acids, is divided into $A$ and $B$ boxes (on the basis of common intron-exon boundaries), and is predicted to fold into two charged amphipathic helices (Bellefroid et al. 1991).

The KRAB domain is a potent, DNA binding-dependent repression domain (Margolin et al. 1994, Witzgall et al. 1994; Pengue et al. 1995; Vissing et al. 1995). The minimal KRAB repression module is $\sim 45$ amino acids, and substitutions for conserved residues within this domain abolish repression. To date, 10 KRAB domains have been demonstrated to be potent repressors, suggesting that this is a common property of independently en- 
Figure 1. Comparison of the KRAB domains from various zinc-finger proteins. The amino acid sequences of $16 \mathrm{KRAB}$ domains (retrieved from sequence data bases and referenced in the text) are aligned. Each gene encodes the indicated $\mathrm{KRAB}$ domain at its amino terminus; the superscript numeral at the left of each sequence indicates the position of the amino acid with respect to the initiator methionine. The zinc fingers encoded by each gene are not shown. The KRAB domain consensus sequence is presented at the top and consensus residues (indicating $>90 \%$ identity) are in bold throughout. Capital, lightface letters in the consensus indicate the next most frequent residue in that position. The substitution mutations $\mathrm{DV} \rightarrow \mathrm{AA}$ and $\mathrm{MLE} \rightarrow \mathrm{KKK}$ in the KOX1 KRAB domain dramatically reduce repression activity (Margolin et al. 1994). A dot in dicates a gap introduced to facilitate alignment.

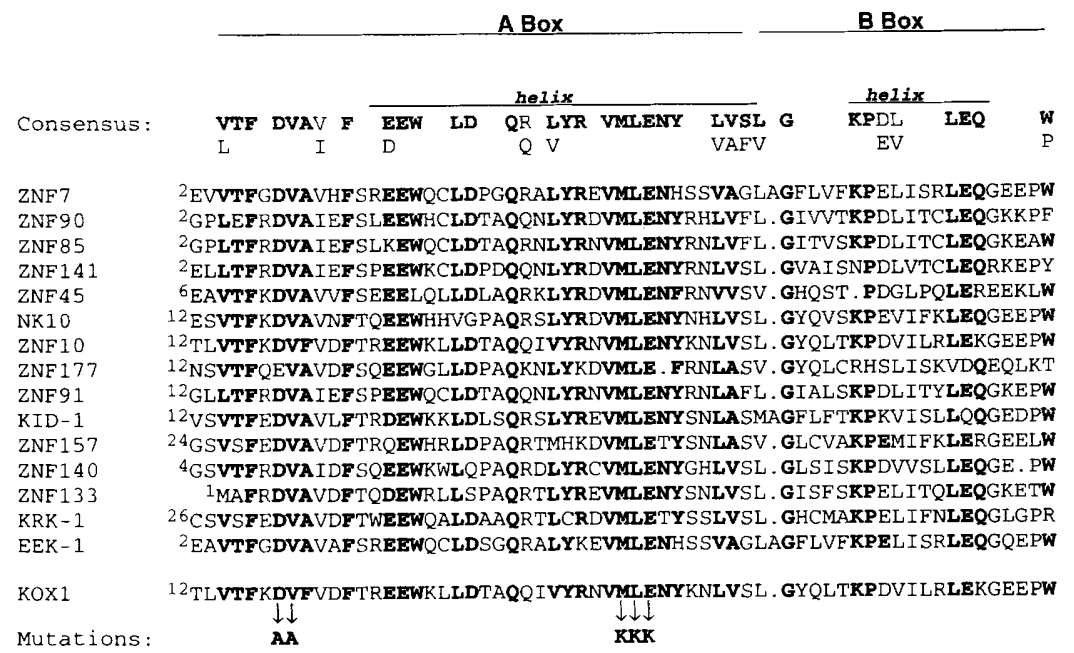

Mutations : coded KRAB domains. Thus, the KRAB-zinc-finger protein (KRAB-ZFP) family represents a large, mechanistically unexplored class of transcriptional repressor molecules.

KRAB-ZFPs are likely to play important regulatory roles during development. Expression of the KRAB-ZFP $\mathrm{KIDl}$ is temporally and spatially restricted to the developing mouse kidney (Witzgall et al. 1993). A cluster of $>40 \mathrm{KRAB}-\mathrm{ZFP}$-encoding genes has been identified on human chromosome 19p12-p13.1, and several members of this cluster are differentially expressed during T-cell ontogeny and activation (Bellefroid et al. 1993). Expression of the KRAB-ZFPs HPF4, HTF10, and HTF34 is down-regulated during myeloid differentiation (Bellefroid et al. 1991). Finally, a number of KRAB-ZFPs are candidate genes for human diseases on the basis of chromosomal location (Tommerup et al. 1993; Crew et al. 1995).

The mechanism of repression by the KRAB domain is not known. In this study, we have identified KRAB-associated protein-1 (KAP-1), a novel protein that binds to the $\mathrm{KRAB}$ domain and functions as a transcriptional corepressor. KAP- 1 is thus a potential mediator of repression for the large class of KRAB domain-containing transcription factors.

\section{Results}

Evidence for a titratable cellular factor required for $K R A B$ domain-mediated repression

The KRAB domain of KOX1 (Fig. 1) is a potent repressor of transcription when fused to the GAL4 DNA-binding domain, and repression by GAL4-KRAB requires DNA binding (Margolin et al. 1994). To determine if a titratable cofactor is involved in repression, we attempted to squelch GAL4-KRAB-mediated repression by cotransfection of a non-DNA-bound KRAB domain expression plasmid (Fig. 2A) (unless otherwise noted, throughout this study the KRAB domain from the KOXl protein was utilized). Typically, squelching refers to the inhibition of transcriptional activation that is observed in the presence of excess non-DNA-bound activator domain; this is thought to reflect competition for a limiting cofactor required for activation by the DNA-bound transcription factor (Gill and Ptashne 1988). By analogy, squelching of repression by the KRAB domain would thus indicate that the KRAB domain functions through a titratable corepressor. As reported previously (Margolin et al. 1994), the GAL4-KRAB fusion protein strongly represses transcription from a reporter plasmid containing five GAL4 UAS binding sites (Fig. 2B, lanes 2,5). However, cotransfection of GAL4-KRAB domain with a plasmid encoding the $\mathrm{KRAB}$ domain alone inhibited repression $>50$-fold in a dose-dependent manner (lanes 3,4,6,7). Transfection of the KRAB domain plasmid alone had little effect on the reporter plasmid (lanes 9,10).

The amino terminus of the WT1 protein lacks a KRAB domain yet exhibits a potent transcriptional repression function when fused to GAL4 (Madden et al. 1991). To determine whether the KRAB repression domain and the WT1 repression domain function via similar titratable cofactors, we attempted to squelch GAL4-WT1-mediated repression with the KRAB-encoding plasmid (Fig. 2B). Transcriptional repression mediated by GAL4-WT1 was unaffected by increasing concentrations of KRAB (lanes 12,13), suggesting that these two repression domains do not share a common target detectable by this squelching assay.

\section{Purification of a 100-kD KRAB domain-binding protein}

We sought to identify cellular factors that bind to KRAB domains using affinity chromatography. We constructed glutathione-S-transferase fusion genes (Fig. 3) encoding the wild-type (GST-KRAB) and a mutant KRAB domain (GST-KRAB, DV $\rightarrow$ AA) that lacks repression activity. 
A

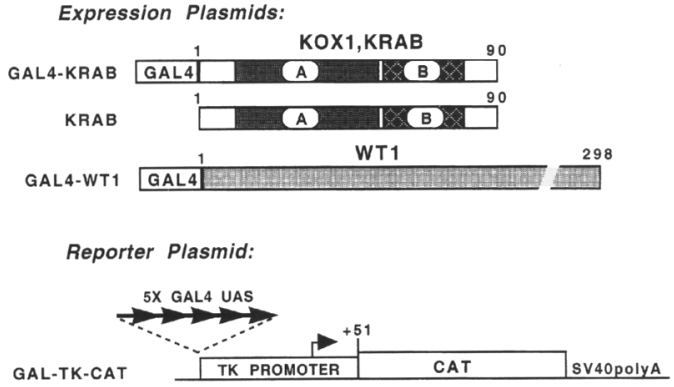

B

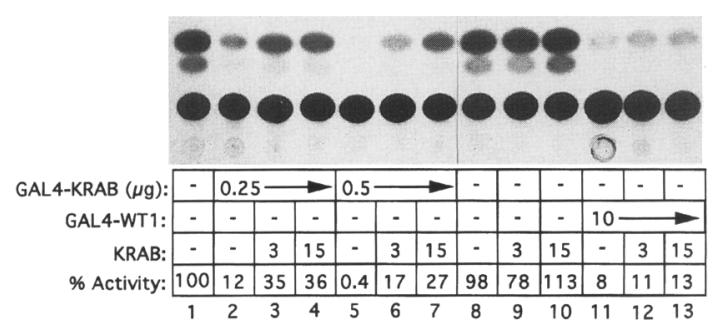

Figure 2. Squelching of KRAB domain-mediated transcriptional repression. $(A)$ Schematic representation of plasmids used in transfection assays. The GAL4(1-147) DNA-binding domain was fused to the indicated regions of the KOX1 KRAB domain and the WT1 repression domain to generate GAL4-KRAB and GAL4-WT1. For squelching, the KRAB domain of KOXl (KRAB) was expressed without a DNA-binding domain. The reporter plasmid (5xGAL4-TKCAT) consists of the CAT gene downstream of the thymidine kinase promoter and five artificial GAL4 upstream activating sequences (UAS). (B) The indicated amounts (in micrograms) of the expression plasmids were transfected with the reporter plasmid into NIH-3T3 cells, and CAT activity in transfected cell extracts was measured and quantified as described in Materials and methods. The amount of activity in the absence of both GAL4-KRAB and GAL4-WT1 was assigned a level of $100 \%$ activity; other levels are expressed relative to this value.

These proteins were soluble and highly expressed in $E$. coli (Fig. 3A). Sepharose beads bound to either wild-type or mutant proteins were incubated with a nuclear extract from $\left[{ }^{35} S\right]$ methionine-labeled cells (Fig. 3B). The beads were washed with stepwise increases in salt concentrations, and the proteins that remained bound after each wash were analyzed by SDS-PAGE (Fig. 3B). A 100$\mathrm{kD}$ protein $(\mathrm{p} 100)$ was retained by the wild-type GSTKRAB resin but did not bind to the GST$\mathrm{KRAB}(\mathrm{DV} \rightarrow \mathrm{AA})$ mutant resin or GST alone. The 100 $\mathrm{kD}$ protein was also retained on the GST-KRAB resin in a single-step purification procedure after extensive washing in buffer containing $0.5 \mathrm{M} \mathrm{NaCl}$ and $0.1 \%$ Triton X-100 (Fig. 3C). GST-fusion proteins encoding KRAB domains from four other proteins, ZNF133, ZNF140, KRK1, and EEK-1 (Fig. $3 \mathrm{C}$ ), bound to p100, suggesting that this may be a general property of KRAB domains. p100 failed to bind to two KRAB-domain substitution mutations $\left(\mathrm{DV} \rightarrow \mathrm{AA}\right.$, Fig. $3 \mathrm{~B}$, and $\mathrm{MLE} \rightarrow \mathrm{KKK}_{\text {; da not }}$ shown) that greatly diminish repression activity (Margolin et al. 1994).

A KRAB-binding protein of identical mobility was also detected in extracts from Rh30, COS1, and RD cells, suggesting that p100 is conserved in mouse, monkey, and human (data not shown). Moreover, when a ${ }^{32} \mathrm{P}$ labeled recombinant KRAB protein was used as a probe in a Far Western blot assay, a $100-\mathrm{kD}$ protein was detected that was not observed when an identical blot was probed with ${ }^{32} \mathrm{P}$-labeled KRAB (DV $\rightarrow$ AA) protein (data not shown). These results suggest that the KRAB-p100 interaction is direct. The correlation between loss of repression and loss of binding to p100 observed with the KRAB mutants indicates that p100 may play a critical role in KRAB-mediated repression.

\section{Cloning of KAP-1}

A preparative-scale purification of KRAB-binding proteins from calf-thymus extract yielded a $100-\mathrm{kD}$ protein that bound to wild-type GST-KRAB but not mutant GST-KRAB(DV $\rightarrow$ AA). The purified protein was subjected to microsequence analysis, and five peptide sequences were obtained. The amino acid sequence of one of the peptides was used to design degenerate oligonucleotide primers that were used in coupled reverse transcription-polymerase chain reaction (RT-PCR). A $70 \mathrm{bp}$ PCR product was found to encode the original peptide sequence and was used as a probe to isolate a $3.1-\mathrm{kb}$ cDNA clone from a human testis cDNA library.

The nucleotide sequence of this clone revealed a 300bp untranslated region (UTR) followed by a $2.5 \mathrm{~kb}$ open reading frame, a $300-$-bp $3^{\prime}-U T R$, and a poly $\left(\mathrm{A}^{+}\right)$tail. The predicted initiator methionine codon is within a favorable sequence context for translation initiation (Kozak 1992) and is immediately preceded by an in-frame stop codon. The longest open reading frame encodes a polypeptide of 835 amino acids (Fig. 4A), with a calculated mass of $89 \mathrm{kD}$ and a $\mathrm{pI}$ of 7.6. In addition, all five peptide sequences obtained in the original purification are encoded by the predicted open-reading frame. A BLAST search (Altschul et al. 1990) with the protein and nucleotide sequences indicated that we had isolated a novel gene which we named $K A P-1$ (KRAB-associated protein-1).

Analysis of the predicted amino acid sequence of KAP-1 revealed several regions similar to previously identified protein motifs (Figs. 4A,B). At the amino terminus a region rich in alanine is followed by a RING finger (which conforms to the consensus $\mathrm{C}_{3} \mathrm{HC}_{4}$ ) and $\mathrm{B} 1$ and $\mathrm{B} 2$ boxes, each of which are regions of conserved cysteine and histidine spacing often found immediately carboxy-terminal to the RING finger (for review, see Freemont 1993). A region of predicted coiled-coil structure (Lupas et al. 1991) is then followed by another cysteine/histidine-rich structure recently identified as a PHD finger (Aasland et al. 1995). The extreme carboxyl terminus displays significant similarity to the bromodomain (Haynes et al. 1992). The overall architecture of KAP-1 is similar to the TIF1 protein (LeDouarin et al. 
Figure 3. Identification and purification of the KRAB-binding protein p100. (A) The GST-KRAB and GST-KRAB(DV $\rightarrow \mathrm{AA})$ fusion proteins (indicated by arrows| were expressed and purified as described in Materials and methods. Each lane represents $20 \mu \mathrm{l}$ of 50:50 slurry separated by SDSPAGE and visualized by Coomassie blue staining. (B) Glutathione-Sepharose beads containing the proteins illustrated in Fig. $A$ were incubated in batch with an $\left[{ }^{35} S \mid\right.$ methionine-labeled $\mathrm{NIH}$ 3T3 nuclear extract and serially washed. Proteins that remained bound after each step were analyzed by SDS-PAGE and fluorography. The arrow indicates p100, a protein which bound to GST-
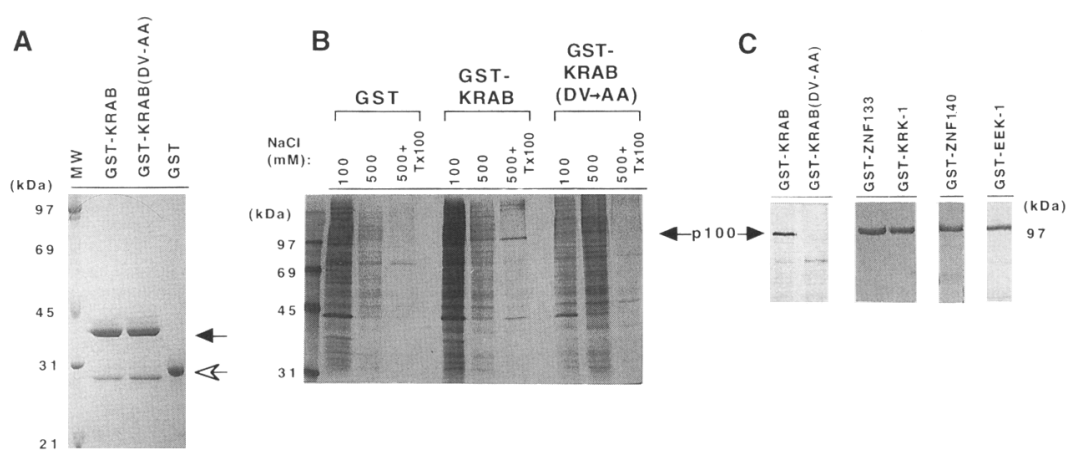

$\mathrm{KRAB}$ (lanes 3-6) but not GST (lanes 1-3) or GST-KRAB(DV $\rightarrow$ AA) (lanes 7-9). The positions of the molecular weight markers are given. $(C)$ The p100 KRAB-binding protein can be purified in a single step and binds to other KRAB domains. (Left) p100 (arrow) was purified as described in $A$ except that six washes at $4^{\circ} \mathrm{C}$ in a buffer containing $0.5 \mathrm{M} \mathrm{NaCl} / 0.1 \%$ Triton-X100 were performed prior to analysis of protein by SDS-PAGE and fluorography. (Right) The KRAB domains derived from the indicated genes were purified as GST-fusion proteins and used to detect binding of p100 (arrow).

1995; Miki et al. 1991), which interacts with the AF-2 region of nuclear hormone receptors (Fig. 4C).

\section{The KAP-1 cDNA encodes a 100-kD KRAB-binding protein}

To verify that the KAP-1 cDNA encodes the $100-\mathrm{kD}$ KRAB-binding protein, we performed coupled in vitro transcription and translation (IVT). A $100-\mathrm{kD}$ protein (Fig. 5A, lane 6) was produced that was immunoprecipitated (lane 5) by antisera raised against recombinant KAP-1 (amino acids 423-589). The KAP-1 antisera immunoprecipitated a protein of identical mobility (lane 2) from ${ }^{35} \mathrm{~S}$-labeled COS1 nuclear extracts. Transfection of an expression vector containing the KAP-1 cDNA into COS1 followed by immunoprecipitation led to an approximately fivefold increase in the amount of this protein (lane 3). We conclude that the KAP-1 cDNA encodes a full-length protein.

To confirm that KAP-1 is identical to the protein we originally purified, we performed a serial GST-KRAB purification/immunoprecipitation experiment using $\mathrm{nu}$ clear extract from KAP-1-transfected COS1 cells (Fig. $5 \mathrm{~B}$ ). To allow us to distinguish endogenous KAP-1 from the product of the transfected KAP-1 cDNA, we placed a seven-residue epitope tag (which is recognized by antimyc monoclonal antibodies) at the carboxyl terminus of KAP-1. Following transfection, the p100 KRAB-binding protein was purified from ${ }^{35} \mathrm{~S}$-labeled COS1 nuclear extracts by use of a GST-KRAB resin (Fig. 5B, lane 4). The protein was then eluted from the resin with glutathione and immunoprecipitated with either anti-KAP-1 serum or myc-tag monoclonal antibody. The $100-\mathrm{kD}$ protein purified on the GST-KRAB resin comigrates with immunoprecipitated KAP-1 (lanes 2 and 3) and is precipitated by the KAP-1 and myc-tag antisera (lanes 6,7 ), but not by preimmune serum (lane 5 ). Identical results were obtained with endogenous KAP-1 protein from COS1 cells in a sequential GST-KRAB Western blot assay (data not shown). These results strongly suggest that the
$K A P-1$ cDNA encodes the p100 KRAB domain-binding protein first identified in nuclear extracts.

\section{KAP-1 forms a ternary complex with a DNA-bound $K R A B$ domain in vitro}

If KAP-1 plays a role in KRAB-mediated repression, it should be able to form a stable complex with a DNAbound KRAB domain. To detect such ternary complexes, we used the electrophoretic mobility shift assay (EMSA). In these experiments the KRAB domain was fused to the DNA-binding domains of the human PAX3 protein. The PAX3-KRAB protein was produced by IVT (Fig. 6A) and DNA binding of the PAX3-KRAB protein was detected via EMSA with a ${ }^{32} \mathrm{P}$-labeled e5 PAX3 recognition sequence (Goulding et al. 1991). When the PAX3-KRAB protein was preincubated with increasing amounts of COS1 nuclear extract, a new complex with reduced mobility was observed (Fig. 6A, lanes 3-6). Incubation of wild-type PAX3 IVT with nuclear extract failed to generate the new complex (data not shown). Moreover, the $\mathrm{PAX} 3-\mathrm{KRAB}(\mathrm{DV} \rightarrow \mathrm{AA})$ protein failed to generate this slowly migrating complex (lanes 8-12) following incubation with nuclear extract. Furthermore, purified, recombinant wild-type KRAB protein but not mutant $\mathrm{KRAB}(\mathrm{DV} \rightarrow \mathrm{AA})$ protein was an effective competitor of complex formation (Fig. 6B).

These data suggest that the new gel shift complex is composed of DNA-bound PAX3-KRAB protein complexed to a KRAB domain-binding protein present in the nuclear extract. We identified this factor as KAP-1 using an extract from COS1 cells transfected with myc-tagged KAP-1 (Fig. 7A); the lower mobility complex was supershifted and/or disrupted by antisera specific for PAX3, KRAB, KAP-1, and the myc epitope (lanes 4-7), but not by preimmune serum (lane 3 ). Together, these results strongly suggest that we have reconstituted the DNAbound KRAB-KAP-1 complex in vitro.

To isolate KRAB-KAP-1 complexes from a cellular milieu, we transfected COS1 cells with the PAX3-KRAB 

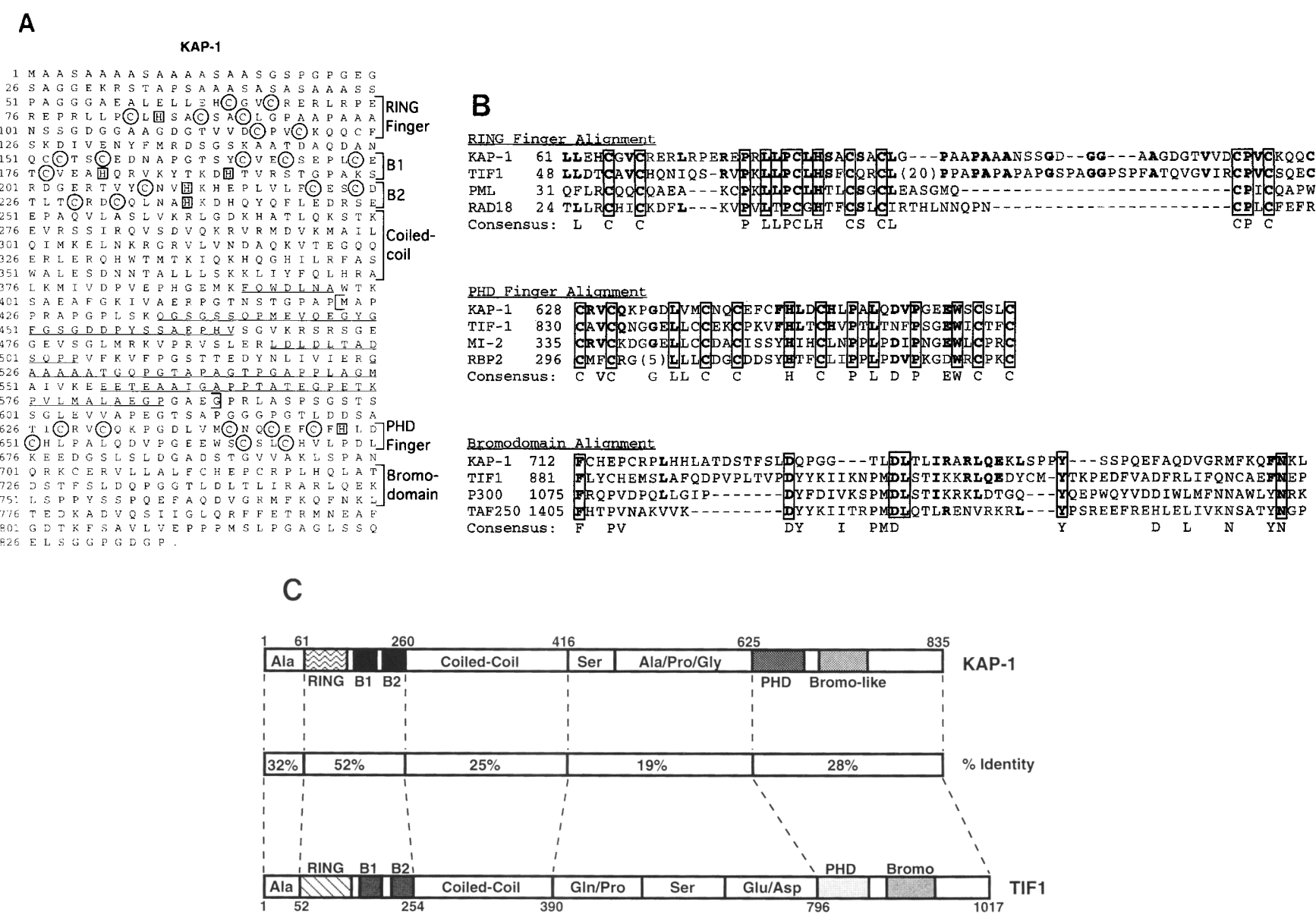

Figure 4. Amino-acid sequence of KAP-1. $(A)$ The predicted amino acid sequence of the protein encoded by the KAP-1 open reading frame. Conserved cysteine and histidine residues of the RING, B1, B2, and PHD fingers are circled. The five peptides originally sequenced are underlined. The relative locations of the RING, B1, B2, coiled-coil, and bromodomains are indicated. The brackets indicate the segment of KAP-1 expressed in Escherichia coli and utilized for antibody production. (B) Alignment of the KAP-1 RING finger, PHD finger, and bromodomain-like regions with the corresponding sequences of related proteins. Residues in aligned proteins that are identical to those of KAP-1 are in bold; those residues present in all four aligned proteins are boxed. For the RING finger and PHD finger alignments, the consensus represents residues conserved in at least three of the four proteins. The bromodomain consensus is taken from Eckner et al. (1994). Dashes indicate gaps inserted for alignment. Accession numbers (NCBI sequence ID): TIF1, 9988 13; PML, 239750; RAD18, 131780; MI-2, 761718; RBP2, 138858; p300, 627657; TAF250, 115942. (C) Comparison of KAP-1 and TIF1. The areas of homology to previously identified motifs are denoted by shaded boxes; regions characterized only by a richness in particular amino acids are indicated. The middle line summarizes the percent identity between KAP-1 and TIF1 by region.

expression plasmid. Nuclear extracts from transfected cells were then tested by EMSA with the ${ }^{32} \mathrm{P}$-labeled e5 DNA binding site (Fig. 7B). The predominant gel shift complex comigrated with the complex reconstituted in vitro, and it was supershifted or disrupted by the PAX3, $\mathrm{KRAB}$, and KAP-1 antisera (Fig. 7B). These results suggest that a stable KRAB-KAP-1 complex is extractable from transfected cells; it remains possible, however, that association occurs after extraction from the nucleus.

The RING-B1-B2 region of KAP-1 is required for binding to the KRAB domain

To identify the region of KAP-1 that is required for the interaction with the $\mathrm{KRAB}$ domain, we constructed an amino-terminal deletion of KAP-1 [KAP-1(239-835)], which lacks the RING-B1-B2 domains (Fig. 8A), but includes the complete predicted coiled-coil domain and the remainder of the protein. As shown in Figure $8 \mathrm{C}$, this KAP-1(239-835) protein was properly expressed in transfected COS1 cells as detected by immunoprecipitation with anti-KAP sera from the nuclear extract (lane 1), but it failed to bind to GST-KRAB resin (lane 2). Note that full-length endogenous KAP-1 is properly bound (lane 2). This suggests that the amino terminus of KAP-l is the site of KRAB binding.

\section{KAP-1 has the functional properties of a corepressor}

One of the defining properties of coactivator/repressor molecules is their ability to influence transcription only when brought to specific target genes by a DNA-bound 
A

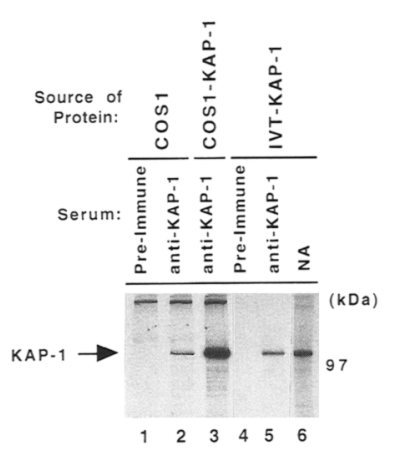

B

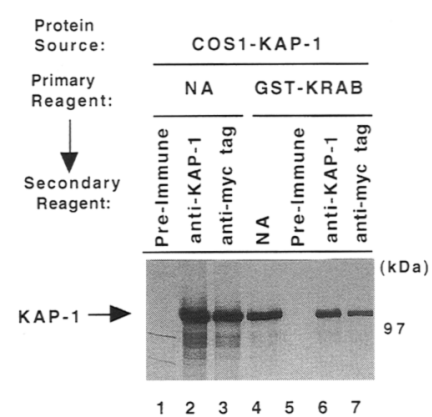

Figure 5. KAP-1 is the p100 KRAB-binding protein initially purified. $(A)$ KAP-1 was immunoprecipitated from $\left[{ }^{35}\right.$ S|methionine-labeled extracts of COSI cells transfected with empty expression plasmid (lanes 1,2) or plasmid including the KAP-1 cDNA (lane 3) with preimmune (lane 1) or KAP-1 antisera (lanes 2,3). The KAP-1 cDNA was transcribed and translated in vitro (KAP-1 IVT, lane 6) and immunoprecipitated with pre-immune and anti-KAP-1 sera (lanes 4,5). The anti-KAP-1 sera were generated as described in Materials and methods. $(B)$ COS1 cells were transfected with a plasmid encoding KAP-1 fused to a carboxy-terminal myc-tag epitope. $\left[{ }^{35} \mathrm{~S} \mid\right.$ methionine-labeled nuclear extracts were either immunoprecipitated with the indicated antisera (lanes 1-3) or used in direct purification on GST-KRABSepharose beads (Pharmacia) (lane 4). For each of lanes 5-7, a GST-KRAB-1 purification twice the scale of that of lane 4 was performed. GST-KRAB-1-binding proteins were then eluted with glutathione and immunoprecipitated with the indicated antisera. For this experiment, the GST-KRAB fusion protein contained the KRAB domain from KRK-1 (Fig. 1). Molecular weight markers are indicated.

transcription factor. This model provided us with two predictions that were tested with regard to KAP-1. First, we expected an increase in the nuclear concentration of KAP-1 to increase the rate of formation of the DNAbound KRAB-KAP-1 complex and, if that step is ratelimiting, to thereby increase the efficiency of KRAB-mediated repression. This prediction was confirmed by the experiment depicted in Figure 8B, in which transfection of increasing amounts of KAP-1 expression vector enhanced repression by PAX3-KRAB up to fivefold, but had a minimal effect in the absence of cotransfected PAX3-KRAB. It is noteworthy that the KAP-1(239-835) protein, which fails to interact with the KRAB domain did not enhance PAX3-KRAB-mediated repression (Fig. $8 \mathrm{C})$. Together, these data suggest that KAP-1 functions as a regulator of transcription when tethered to DNA through protein-protein interactions with the KRAB domain.

The second property expected of a corepressor is the ability to affect transcription in the absence of its natural binding partner when directly tethered to DNA. To test this prediction, we fused KAP-1 amino acids 293-835 to the GAL4(1-147) DNA-binding domain. The amino-terminal RING-B1-B2 structures were not included, thereby ensuring that any effect on transcription was not attributable to interactions with endogenous KRAB-con- taining proteins. The GAL4-KAP-1, 293-835 fusion protein significantly repressed transcription of the 5xGAL4TKCAT reporter (Fig. 9A).

In summary, these data suggest that KAP-1 contains an intrinsic DNA binding-dependent repression function and supports the model that KAP-1 is a corepressor that mediates repression by the KRAB domain.

\section{Discussion}

We have utilized the KRAB repressor domain to identify and clone a gene encoding a novel nuclear protein (KAP1) that displays the hallmarks of a corepressor. We offer a number of lines of evidence that suggest that KAP-1 plays a key role in mediating KRAB domain repression: (1) KAP-1 binds to multiple KRAB repression domains and the KRAB-KAP-1 interaction can be reconstituted in vitro; (2) mutations in the KRAB domain that abolish repression concomitantly abolish the interaction with KAP-1; (3) overexpression of KAP-1 enhances KRAB-mediated repression in a manner dependent on the presence of the domain in KAP-1 that binds the KRAB domain; and (4) KAP-1 itself is a repressor when fused to a DNAbinding domain. Together, these findings are consistent with a simple model in which a DNA-bound KRAB domain recruits the KAP-1 corepressor to the promoter via direct protein-protein interactions (Fig. 9B). Repression based on recruitment of a corepressor may be similar to hairy-groucho interactions in Drosophila (Paroush et al. 1994), MATa2/MCM1-SSN6/TUPI interactions in yeast (Keleher et al. 1992; Cooper et al. 1994; Tzamarias and Struhl 1994), p53-E1b (Yew et al. 1994), thyroid hormone receptors-N-CoR, or SMRT interactions /Chen and Evans 1995; Horlein et al. 1995) in mammalian cells. It will be interesting to determine whether the mechanisms utilized by these corepressor molecules converge at a common step in the transcriptional initiation process.

KAP-1 encodes at least four different classes of cysteine/histidine-rich motifs: The RING finger, B1 box, B2 box, and PHD finger. These structural motifs support its role as a corepressor and also suggest potential mechanisms of repression. The amino-terminal RING finger motif is identified by the signature $\mathrm{C}_{3} \mathrm{HC}_{4}$ spacing of cysteine and histidine residues (Freemont 1993), and our data support its proposed function as a protein-protein interface (Barlow et al. 1994; Borden et al. 1995). RINGfinger-containing proteins have been strongly implicated in cell growth regulation and transcription; these genes include the tumor suppressor BRCA-1 (Miki et al. 1994), the proto-oncogene PML, which is fused to the retinoicacid receptor- $\alpha$ (RAR $\alpha)$ in acute promyelocytic leukemia (Kakizuka et al. 1991), and the Drosophila protein msl-2 (Kelley et al. 1995; Zhou et al. 1995). msl-2 is particularly suggestive of a role for the RING finger in the regulation of chromatin structure; it is localized to male X chromosome chromatin and is required for the hypertranscription that is responsible for Drosophila dosage compensation. 
A

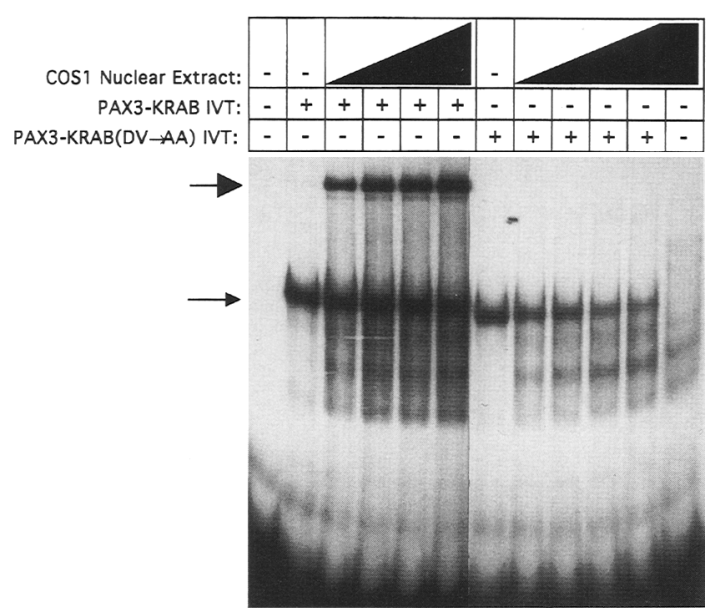

B

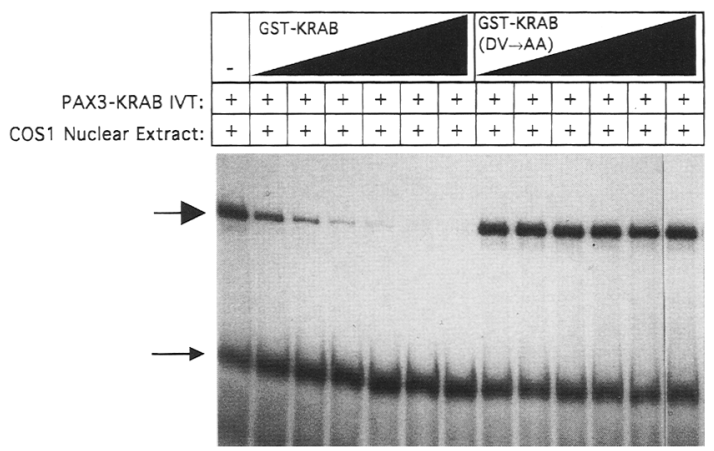

PAX3-KRAB:

\begin{tabular}{|c|c|c|}
\hline PAX & $381)$ & $\mathrm{KOX} 1$ \\
\hline paired IV & Qhomeot & KRAB \\
\hline
\end{tabular}

PAX3-KRAB(DV-AA):

\begin{tabular}{|c|c|c|}
\hline PAX & 381) & KOX1 \\
\hline paired & homeo & KRAB \\
\hline
\end{tabular}

Figure 6. Detection of DNA-bound KRAB-KAP-1 complexes formed in vitro. $|A|$ The binding of PAX3-KRAB to COS1 nuclear proteins was detected by EMSA with in vitro translated PAX3-KRAB (lanes 2-6), PAX3-KRAB(DV $\rightarrow$ AA) (lanes 7-12), a ${ }^{32}$ P-labeled DNA probe containing the e5 PAX3 binding site, and a COS1 nuclear extract, as described in Materials and methods. The specific e5-binding complex formed in the absence of COS1 nuclear extract is indicated by a small arrow; the more slowly migrating complex formed upon addition of the nuclear extract is indicated by a large arrow. $(B)$ Competition of higher-order complex formation by purified GST-KRAB $(0.6,1.25,2.5,5,10$, and $20 \mu \mathrm{g}$; lanes 2-7) or GST-KRAB(DV $\rightarrow$ AA) $\{0.6,1.25,2.5,5,10$, and 20 $\mu$; lanes 8-13). The EMSA was performed as in $A$, but with a constant amount of COS1 nuclear extract. GST-fusion proteins were expressed in bacteria, purified on glutathione-Sepharose (Pharmacia), and eluted with glutathione as described in Materials and methods.

The PHD finger is a cysteine/histidine-rich structure that is distinguished from the RING finger and LIM domain by containing a consensus of $\mathrm{C}_{4} \mathrm{HC}_{3}$ that spans 50-80 residues (Aasland et al. 1995). Many PHD-fingercontaining proteins have been implicated in chromatinmediated transcriptional modulation. These include products of the Drosophila genes trithorax and polycomblike and the human gene HRX, which is fused to AF10/AF17 in the t(11:17) translocation in acute leukemia (Chaplin et al. 1995). Likewise, although the bromodomain of KAP-1 is imperfect, it is interesting to note that bromodomains are found in the adaptor proteins p300, CBP, and GCN5, as well as in the SWI2/SNF2 component of the yeast SWI/SNF transcriptional activation complex of proteins (Laurent et al. 1991; Yoshimoto and Yamashita 1991; Georgakopoulos and Thireos 1992; Chrivia et al. 1993; Eckner et al. 1994). Thus, the overall organization of KAP-1 supports its classification as a corepressor and leads to the speculation that KAP-1 represses transcription by a chromatin-mediated mechanism.

The protein most homologous to KAP-1 is TIF1, a putative coactivator for nuclear hormone receptor-mediated transcriptional activation (LeDouarin et al. 1995). TIF1 was cloned in a yeast two-hybrid screen for proteins that are able to enhance transactivation by the AF-2 region of the retinoid-X receptor- $\gamma(\operatorname{RXR} \gamma)$, and it was found to interact with several members of the nuclear hormone receptor family. Although KAP-1 and TIF1 share a remarkably similar organization of motifs, they are clearly not encoded by the same gene: The overall amino acid sequence homology is only $31 \%$. The loop region between $\mathrm{C} 5$ and $\mathrm{C} 6$ of the TIF1 RING is much longer and highly divergent compared with the analogous region in KAP-1. In addition, the regions between the coiled-coil domain and the PHD fingers of KAP-1 and TIF1 are only weakly similar. Finally, the amino-acid sequence of the TIF1 bromodomain conforms much more stringently to the consensus that defines the domain than does that of KAP-1. Whether the similarity between KAP-1 and TIF1 is actually reflected in significant cross-talk between the hormone receptor and KRAB-ZFP families of transcription factors is an intriguing question and remains to be tested.

In conclusion, we have isolated a corepressor, KAP-1, for the KRAB repression domain. This discovery provides a new and potentially unifying paradigm for the enormous number of KRAB-domain-containing zinc-finger proteins in the human genome. A future determination of the downstream targets of KAP-1 may yield im- 


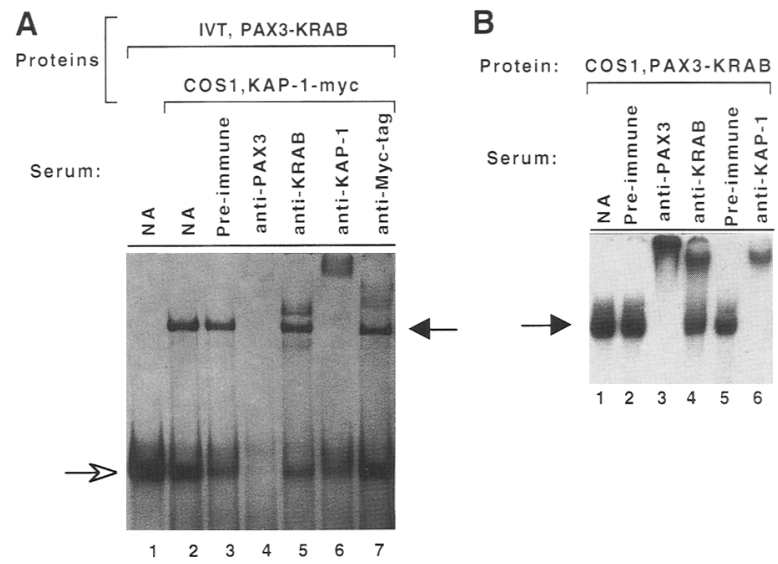

Figure 7. Identification of components of the KRAB-KAP-1 complex. $(A)$ Use of specific antisera to identify components of the e5-binding complex. The EMSA was performed as in Fig. 6A, with the addition of the indicated antisera to the binding reactions. $(B)$ Detection of PAX3-KRAB-KAP-1 complexes in nuclear extracts. The EMSA was performed using the ${ }^{32} \mathrm{p}$-labeled e5 probe and nuclear extract from COS1 cells transfected with an expression plasmid encoding PAX3-KRAB. Antisera were added to the binding reactions as indicated. The arrow indicates the specific e5 binding complex containing PAX3-KRAB-KAP-1.

portant mechanistic insights into transcriptional repression.

\section{Materials and methods}

\section{Expression and reporter vectors}

The plasmids encoding the GAL4(1-147) fusions to $\operatorname{KOXI}(1-90)$, $\mathrm{KOXl}(1-90 ; \mathrm{DV} \rightarrow \mathrm{AA})$, and to WT1(1-298) have been described (Madden et al. 1993; Margolin et al. 1994). For the squelching experiments, $\mathrm{KOXl(1-161)}$ was subcloned into the $\mathrm{pCB}^{+}{ }^{+}$expression vector. The GAL4-KAP-1 plasmid was generated from a partial KAP clone isolated from a $\lambda Z A P$ NK cell library (Stratagene) that includes KAP-1 nucleotides 718-2679 (amino acid residues 293-837) flanked by EcoRI sites. This EcoRI fragment was subcloned into the EcoRI site of the pM2 GAL4-fusion mammalian expression plasmid (Sadowski et al. 1992). The 5xGAL4-TKCAT and TKCAT reporter plasmids have been described by Shi et al. (1991). The PAX3-KRAB (1-381) fusion genes were constructed by use of the PAX3-FKHR plasmid described in Fredericks et al. (1995). KOXl(1-90) and the DV $\rightarrow$ AA mutant were subcloned into the EcoRI and $X b a \mathrm{I}$ sites, thereby replacing the FKHR sequences. The reporter plasmid for the PAX-KRAB fusions 2xe5TKCAT has been described (Fredericks et al. 1995).

\section{Cell culture, transfections, and CAT assays}

NIH-3T3 mouse cells, human Rh30, and COS1 monkey kidney cells were grown and transfected as described (Margolin et al. 1994). Expression of all constructs was confirmed by immunoprecipitation with the appropriate antisera (Madden et al. 1991, 1993; Morris et al. 1991). The CMV vector expressing $\beta$-D-galactosidase, p0N260, was used in all transfections, and $\beta$-D-galactosidase activity was used to normalize transfection efficiency in cell extracts for the CAT assay. Cell harvesting, CAT assays, and quantitation were performed as described (Madden
1991, 1993). Each transfection experiment was performed at least three times in duplicate. The numbers derived are the averages of duplicates in a single experiment and variability was within $10 \%$.

Generation of GST-fusion proteins and purification of KAP-1

The cDNAs encoding KOXl(1-90) and the DV $\rightarrow$ AA mutant were subcloned into the pGEX-2TK vector (Pharmacia). The ZNF133 and ZNF140 GST-fusion plasmids were generated with cDNAs kindly provided by H.-J. Theisen. Regions of each cDNA including the KRAB domain (ZNF133 residues $1-198$ and

\section{A}

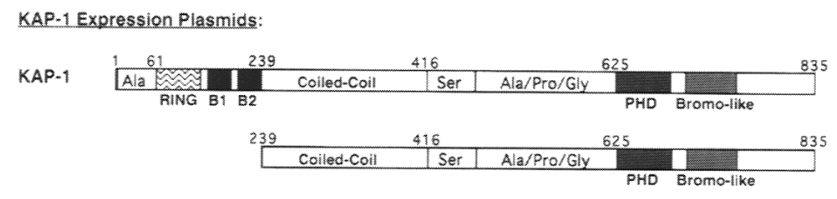

B
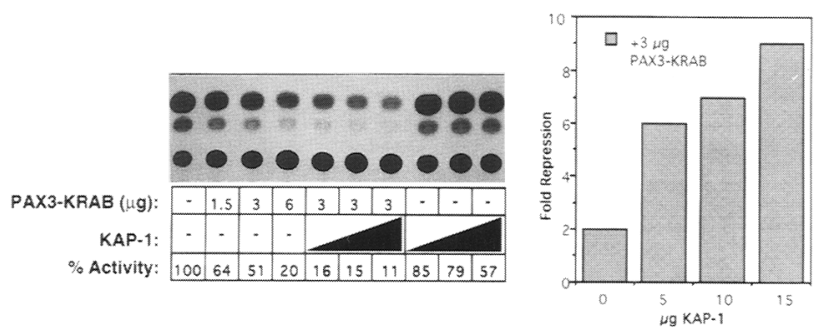

C
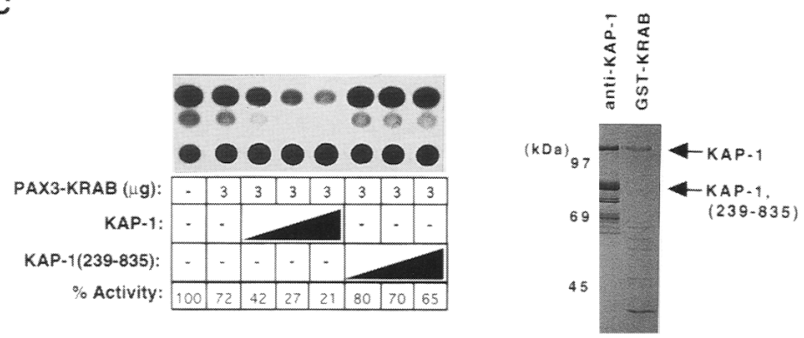

Figure 8. Enhancement of KRAB-mediated repression by exogenous KAP-1. $\{A, B)$ Cells were transfected with the indicated amounts (in micrograms) of expression plasmid encoding PAX3-KRAB, and with $5 \mu \mathrm{g}$ (lanes 5,8), $10 \mu \mathrm{g}$ (lanes 6,9), or 15 $\mu \mathrm{g}$ (lanes 7,10 ) of expression plasmid encoding KAP-1 or KAP1(239-835), along with $2.5 \mu \mathrm{g}$ of the reporter plasmid. The CAT assay and quantification were performed as described in Materials and methods. The amount of CAT activity in the absence of PAX3-KRAB and KAP-1 was assigned a level of $100 \%$ activity; other activities are reported as a percentage of this value. The degree of repression by $3 \mu \mathrm{g}$ of PAX3-KRAB expression plasmid in the presence of $0,5,10$, and $15 \mu \mathrm{g}$ of KAP-1 plasmid is graphically represented in the right panel. $(C)$ Deletion of the RING-B1-B2 eliminates both binding to the KRAB domain and enhancement of KRAB-mediated repression. An expression plasmid encoding KAP-1(239-835) was transfected into COS1 cells, and transfected cell extracts were used in an anti-KAP-1 immunoprecipitation (lane 1) or purification on GST-KRAB bound to glutathione-Sepharose (lane 2). Full-length endogenous KAP-1 and exogenous KAP-1(239-835) are indicated by arrows. 
A

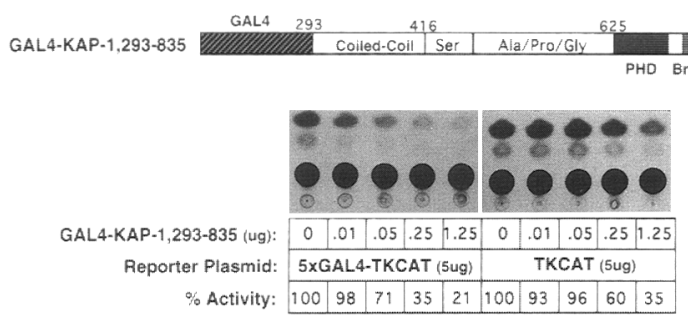

B

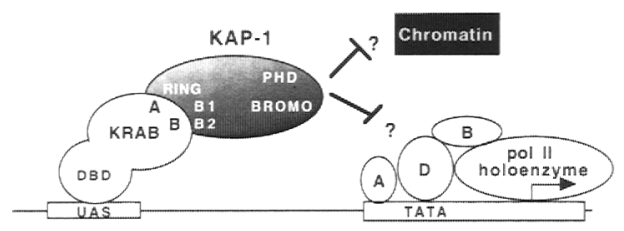

Figure 9. Repression by a GAL4-KAP-1 fusion protein. (A) Increasing amounts of GAL4-KAP-1(293-835) expression plasmid $(0.01,0.05,0.25$, and $6.25 \mu \mathrm{g}$; lanes $2-6$ and 8-12) were transfected into NIH-3T3 cells with either the 5xGAL4-TKCAT reporter (lanes 1-6) or the TKCAT reporter (lanes 7-12). The amount of CAT activity for each reporter in the absence of GAL4-KAP-1(293-835) was assigned a level of $100 \%$ activity; other activities are reported as a percentage of this value. $(B) \mathrm{A}$ model of KRAB-ZFP-KAP-1 interactions which may mediate repression. We suggest that a KRAB-ZFP protein bound to its cognate recognition sequence recruits the KAP-1 corepressor via protein-protein interactions /although the sequence of events is unknown). The RING-B1-B2 region of KAP-1 is necessary (but may not be sufficient) for this interaction. The intrinsic repression domain of KAP-1 nominally comprised of the carboxy-terminal segment containing the PHD and bromodomains then mediates repression. It is speculated that the mechanisms of KAP-1-mediated repression involve chromatin structure alteration (signified by the black box) or direct interactions with components of the basal transcription machinery.

ZNF140 residues 1-137) were cloned into the vectors pGEX4T-3 and pGEX-2TK, respectively. The GST-KRK-1 fusion plasmid was generated by the subcloning of a region including the KRAB domain (residues 30-290) into the pGEX-4T-3 vector. All GST-fusion proteins were expressed in bacteria and purified according to the manufacturer's instructions (Pharmacia). We routinely obtained $>98 \%$ purity at concentrations of $1-2 \mu \mathrm{g}$ of GST-KRAB protein bound per $5 \mu \mathrm{l}$ of 50:50 Sepharose slurry. For analytical purification of KAP-1 from NIH-3T3 cells, $\left[{ }^{35} \mathrm{~S}\right]$ methionine labeling and nuclear extract preparation were performed as described (Fredericks et al. 1995). Labeled nuclear extract $(50 \mu \mathrm{d})$ was precleared for $1 \mathrm{hr}$ at $4^{\circ} \mathrm{C}$ with $20 \mu \mathrm{l}$ of GST-Sepharose $(\sim 5 \mu \mathrm{g}$ protein $/ \mu \mathrm{l}$ resin) in a total volume of 1 $\mathrm{ml}$ of NEB (10 mM HEPES, pH 7.6, 20\% glycerol, $0.5 \mathrm{M} \mathrm{NaCl}, 1.5$ $\mathrm{mM} \mathrm{MgCl}_{2}, 0.2 \mathrm{~mm}$ EDTA, $0.1 \%$ Triton-X100). The precleared nuclear extract was then allowed to associate with $50 \mu \mathrm{l}$ of GST-KRAB-Sepharose for $1 \mathrm{hr}$ at $4^{\circ} \mathrm{C}$. The beads were washed $5 \times$ with $1 \mathrm{ml}$ of NEB, boiled in $2 \times$ SDS gel loading buffer, and analyzed by SDS-PAGE and fluorography.

The preparative scale purification of KAP-1 was conducted with a calf thymus extract prepared at $4^{\circ} \mathrm{C}$ as follows: $\sim 10 \mathrm{~cm}^{3}$ of calf thymus was frozen in liquid nitrogen and pulverized. The powder was diluted to three times its original volume with hypotonic buffer $(\mathrm{HB})$ plus protease inhibitors (10 $\mathrm{mM}$ HEPES, pH 7.5, 1 mM DTT, 0.1 mM EDTA, 0.1 mM EGTA, 1 mM PMSF, $2 \mu \mathrm{g} / \mathrm{ml}$ leupeptin, $2 \mu \mathrm{M}$ pepstatin $\mathrm{A}$, and $0.04 \mathrm{U} / \mathrm{ml}$ aprotinin), and homogenized in a Waring blender and Dounce homogenizer. $\mathrm{KCl}$ and glycerol were added to $500 \mathrm{~mm}$ and $20 \%$, respectively, and the extract was centrifuged at $146,000 \mathrm{~g}$ for $1 \mathrm{hr}$. Proteins in the supernatant were fractionated by $33 \%$ ammonium sulfate precipitation. The resulting precipitate was resuspended in $20 \mathrm{ml}$ of NEB and dialyzed exhaustively in the same buffer. Approximately $10 \mathrm{ml}$ of this calf thymus extract was loaded onto a l-ml bed volume GST-fusion protein-glutathione-Sepharose column; the column was washed with $>5$ bed volumes of NEB $+1 \%$ Triton-X100, and eluted with three bed volumes of elution buffer $(20 \mathrm{~mm}$ glutathione, $100 \mathrm{~mm}$ Tris$\mathrm{HCl}, \mathrm{pH} 8.0$, and $120 \mathrm{~mm} \mathrm{NaCl}$. The column fractions were analyzed by SDS-PAGE and Coomassie blue staining. Selected fractions from several purifications were pooled and concentrated in Centricon- 50 concentrators according to the manufacturer's instructions (Amicon). A total of $\sim 50 \mu \mathrm{g}$ of KAP-1 was obtained from $\sim 100 \mathrm{gm}$ of frozen calf thymus, the result of three independent purification procedures. Protein blotting, in situ trypsin digestion, reverse phase HPLC separation of peptides, mass spectrometry analysis of fractions, and peptide microsequencing were performed by the Wistar Protein Microsequencing Facility as described in Best et al. (1995).

\section{Cloning of KAP-1}

The sequence of the peptide QGSGSSQPMEVQEGYGFGSGDDPYSSAEPH was used to design a degenerate primer pair (including BamHI and EcoRI sites to facilitate cloning) for use in RT-PCR. The template for RT-PCR was poly(A+ $\mathrm{A}^{+}$bovine kidney RNA (Clontech). The RT-PCR was performed as follows: 1 $\mu g$ of poly $\left(\mathrm{A}^{+}\right) \mathrm{RNA}$ was reverse-transcribed with an oligo(dT) primer and SuperScript II enzyme (Gibco-BRL) according to the manufacturer's instructions. A fraction of the reverse-transcription reaction was then amplified by PCR with the degenerate primer pair under the following conditions: $37^{\circ} \mathrm{C}, 15 \mathrm{~min}$, followed by five cycles of $94^{\circ} \mathrm{C}, 30 \mathrm{sec} ; 37^{\circ} \mathrm{C}, 30 \mathrm{sec} ; 70^{\circ} \mathrm{C}, 2 \mathrm{~min}$; and 30 cycles of $94^{\circ} \mathrm{C}, 30 \mathrm{sec}^{\circ} 48^{\circ} \mathrm{C}, 30 \mathrm{sec}^{\circ} 70^{\circ} \mathrm{C}, 1.5 \mathrm{~min}$. A 70-bp product was gel-purified, digested with $\mathrm{BamHI}$ and EcoRI, and cloned into the pGEM-7zf $|+|$ plasmid (Promega). The DNA sequence of the clone was found to encode the original peptide in a single reading frame. A human expressed sequence tag that displayed $98 \%$ nucleotide sequence identity to the 70 -bp product was used as a hybridization probe to isolate a $3.1-\mathrm{kb}$ cDNA clone from a human testis cDNA library (Clontech). The KAP-1 cDNA was subcloned into the pcDNA3 vector (Invitrogen) for in vitro transcription and expression in mammalian cells. The modified 7 residue myc-tag amino acid sequence, EQKLISE, was fused to the carboxyl terminus by incorporating it into an oligonucleotide primer followed by PCR. The KAP-1(239-835) deletion was constructed by PCR of the entire region using a $5^{\prime}$ primer which included a Kozak consensus sequence (Kozak 1992) and an initiator methionine codon. The resulting product was cloned into the pCDNA3 mammalian expression vector (Invitrogen). All PCR products were sequenced on both strands to guard against errors.

\section{Sequence analysis}

The KAP-1 cDNA was sequenced on both strands by a combination of manual dideoxy sequencing (Ausubel et al. 1994) and automated sequencing on an Applied Biosystems cycle sequencing apparatus. DNA and protein sequence homology searches 
were performed by use of the BLAST network service /Altschul et al. 1990).

\section{Antisera, immunoprecipitations, and immunohistochemistry}

Nucleotides $1270-1755$ of the KAP-1 cDNA were amplified by PCR and subcloned into the PQE30 hexahistidine-fusion bacterial expression vector (Qiagen), expressed in bacteria, and purified by nickel-chelate chromatography (Qiagen). Then hexahistidine-tagged KAP-1 $(423-584)$ was used to generate anti-KAP-1 sera in $\mathrm{C} 3 \mathrm{H}$ mice. Soluble protein was mixed with Freund's adjuvant and injected subcutaneously. The bleeds from five mice were pooled and tested in immunoprecipitations of labeled, in vitro transcribed/translated KAP-1. The same single bleed pool was used in all experiments. The anti-KOX1 serum was generated in rabbits against hexahistidine-KOX1(1-161) and anti-PAX3 serum was generated as described (Fredericks et al. 1995).

For immunoprecipitations, COS1 cells were labeled with $\left[{ }^{35} \mathrm{~S}\right]$-methionine and harvested in ELB buffer plus protease inhibitors (250 mM NaCl, $50 \mathrm{~mm}$ HEPES, $\mathrm{pH} 7.5,0.1 \% \mathrm{NP}-40,1$ mM EDTA, $0.1 \mathrm{mM}$ PMSF, $2 \mu \mathrm{g} / \mathrm{ml}$ leupeptin, and $11 \mu \mathrm{g} / \mathrm{ml}$ aprotinin). Immunoprecipitations were performed in $1 \mathrm{ml}$ of ELB plus protease inhibitors. One microliter of preimmune or anti-KAP-1 sera (or $1 \mu \mathrm{g}$ of myc-tag monoclonal antibody) was added and incubated for $2 \mathrm{hr}$ at $4{ }^{\circ} \mathrm{C}$, followed by the addition of $100 \mu \mathrm{l}$ of a $10 \%$ slurry of Protein A-Sepharose (Pharmacia) and rotation at $4^{\circ} \mathrm{C}$ for $30 \mathrm{~min}$. The pellets were washed five times with $1 \mathrm{ml}$ of ELB, boiled in $2 \times$ SDS gel loading buffer, and analyzed by SDS-PAGE and fluorography. For the sequential GST association/immunoprecipitations, proteins bound to GST-KRAB were eluted in batch in five bed volumes of elution buffer ( $20 \mathrm{mM}$ glutathione, $100 \mathrm{~mm}$ Tris- $\mathrm{HCl}, \mathrm{pH} 8.0$, and 120 $\mathrm{mM} \mathrm{NaCl}$ ) at room temperature for $30 \mathrm{~min}$. Eluted proteins were then immunoprecipitated in $1 \mathrm{ml}$ ELB as described above.

\section{Electrophoretic mobility shift assay}

EMSA was performed essentially as described (Fredericks et al. 1995). The PAX3-KRAB fusion protein was transcribed/translated in vitro and used in all assays unless otherwise noted. Binding reactions were assembled in $20 \mu \mathrm{l}$ of binding buffer (final concentration $20 \mathrm{~mm}$ HEPES ( $\mathrm{pH} 7.6$ ), $50 \mathrm{~mm} \mathrm{NaCl}, 0.2 \mu \mathrm{g}$ poly [d(I-C)], $0.5 \mathrm{~mm} \mathrm{DTT,} 5 \mathrm{~mm} \mathrm{MgCl}_{2}, 10 \%$ glycerol). In vitro translated PAX3-KRAB was incubated in the above buffer with nuclear extracts/antisera/competitor proteins for $20 \mathrm{~min}$ at room temperature, and then $1 \mu \mathrm{l}$ of e 5 probe $\left(10^{5} \mathrm{cpm} / \mu \mathrm{l}\right)$ was added and the reaction was incubated for $10 \mathrm{~min}$ at $30^{\circ} \mathrm{C}$. Amounts of antibodies used were as follows: $1 \mu \mathrm{l}$ of a 1:10 dilution of anti-KAP-1 sera, $1 \mu$ lanti-PAX3 sera, $1 \mu l$ of a $1: 5$ dilution of anti-KOXl sera, or $0.1 \mu \mathrm{g}$ myc-tag monoclonal antibody. In experiments involving addition of competitor proteins, GST-KRAB and GST-KRAB(DV $\rightarrow$ AA) were purified on glutathione-Sepharose and eluted as described above. For assays of PAX3-KRAB complexes formed in vivo, PAX3-KRAB and KAP-1 expression plasmids were transfected into COS1 cells, and nuclear extracts were prepared as described above. DNAprotein complexes were resolved on $1.5-\mathrm{mm} 4.5 \%$ native polyacrylamide gels by electrophoresis at $400 \mathrm{~V}$ for $1 \mathrm{hr}$ in $45 \mathrm{~mm}$ Tris-borate $(\mathrm{pH} 8.3) / 45 \mathrm{~mm}$ boric acid per $1 \mathrm{~mm}$ EDTA buffer. EMSA gels were dried and visualized by autoradiography.

\section{Acknowledgments}

We thank Drs. Amitabha Basu and Chin Howe for assistance with thymus extract preparation; Dr. Gerd Maul for immunofluorescence analyses, Dr. Laura Benjamin for assistance with
RT-PCR assays, David Reim and the Wistar Institute Microchemistry Core Facility for peptide sequencing, Drs. Hildegund C.J. Ertl and Zhi Quan Xiang for assistance in production of polyclonal mouse sera, and Dr. Cory Abate (Center for Advance Biotechnology and Medicine) for the gift of anti-myc-tag monoclonal antibody. We also thank Drs. Shelley Berger, Mitch Lazar, Henrik Vissing (Novo Nordisk, Denmark), George Prendergast, Paul Lieberman, Giovanni Rovera, and Peter Traber for helpful discussion and Dawna Gillespie for preparation of the manuscript. J.R.F. is supported by the Medical Science Training Program, University of Pennsylvania School of Medicine. W.J.F. is supported by the Wistar Institute Cancer Training Grant CA09171. D.E.J. is supported by a Susan G. Komen Breast Cancer Foundation Fellowship. E.G.N. is supported by DK49210 and DK45191. D.W.S. is supported by CA66671 and CA25874. F.J.R. is supported by National Institutes of Health grants CA52009, Core grant CA10815, DK49210, GM54220, DAMD17-96-1-6141, ACS NP-954, and the Irving A. Hansen Memorial Foundation, the Mary A. Rumsey Memorial Foundation, and the Pew Scholars Program in the Biomedical Sciences.

The publication costs of this article were defrayed in part by payment of page charges. This article must therefore be hereby marked "advertisement" in accordance with 18 USC section 1734 solely to indicate this fact.

\section{References}

Aasland, R., T.J. Gibson, and A.F. Stewart. 1995. The PHD finger: Implications for chromatin-mediated transcriptional regulation. Trends Biochem. Sci. 20: 56-59.

Altaba, A., H. Perry-O'Keefe, and D.A. Melton. 1987. Xfin: An embryonic gene encoding a multifingered protein in Xenopus. EMBO \%. 6: 3065-3070.

Altschul, S.F., W. Gish, W. Miller, E.W. Myers, and D.J. Lipman. 1990. Basic local alignment search tool. I. Mol. Biol. 215: 403-410.

Ascoli, C.A. and G.G. Maul. 1991. Identification of a novel nuclear domain. I. Cell Biol. 112: 785-795.

Ausubel, F.M., R. Brent, R.E. Kingston, D.D. Moore, J.G. Seidman, J.A. Smith, and K. Struhl. 1994. Current protocols in molecular biology, Vol. 12. John Wiley and Sons, New York, NY.

Ayer, D.E., Q.A. Lawrence, and R.N. Eisenman. 1995. Mad-Max transcriptional repression is mediated by ternary complex formation with mammalian homologs of yeast repressor Sin3. Cell 80: 767-776.

Baniahmad, A., X. Leng, T.P. Burris, S.Y. Tsai, M.J. Tsai, and B.W. O'Malley. 1995. The tau 4 activation domain of the thyroid hormone receptor is required for release of a putative corepressor(s) necessary for transcriptional silencing. Mol. Cell. Biol. 15: 76-86.

Barlow, P.N., B. Luisi, A. Milner, M. Elliott, and R. Everett. 1994. Structure of the C3HC4 domain by $1 \mathrm{H}$-nuclear magnetic resonance spectroscopy. A new structural class of zincfinger. I. Mol. Biol. 237: 201-211.

Bellefroid, E.J., D.A. Poncelet, P.J. Lecocq, O. Revelant, and J.A. Martial. 1991. The evolutionarily conserved Kruppel-associated box domain defines a subfamily of eukaryotic multifingered proteins. Proc. Natl. Acad. Sci. 88: 3608-3612.

Bellefroid, E.J., J.C. Marine, T. Ried, P.J. Lecocq, M. Riviere, C. Amemiya, D.A. Poncelet, P.G. Coulie, P. de Jong, C. Szpirer, D.C. Ward, and J.A. Martial. 1993. Clustered organization of homologous $\mathrm{KRAB}$ zinc-finger genes with enhanced expression in human T lymphoid cells. EMBO J. 12: 1363-1374.

Best, S., D.F. Reim, J. Mozdzanowski, and D.W. Speicher. 1995. 
High sensitivity peptide sequence analysis using in situ proteolysis on high retention PVDF membranes and a biphasic reaction column sequencer. In Techniques in protein chemistry $V$ (ed. J.W. Crabb), pp. 565-574. Academic Press, San Diego, CA.

Borden, K.L., M.N. Boddy, J. Lally, N.J. O'Reilly, S. Martin, K. Howe, E. Solomon, and P.S. Freemont. 1995. The solution structure of the RING finger domain from the acute promyelocytic leukaemia proto-oncoprotein PML. EMBO $/$. 14: 1532-1541.

Chaplin, T., O. Bernard, H.B. Beverloo, V. Saha, A. Hagemeijer, R. Berger, and B.D. Young. 1995. The $t(10 ; 11)$ translocation in acute myeloid leukemia (M5) consistently fuses the leucine zipper motif of AF10 onto the HRX gene. Blood 86: 2073-2076.

Chen, J.D. and R.M. Evans. 1995. A transcriptional co-repressor that interacts with nuclear hormone receptors. Nature 377: 454-457.

Chrivia, J.C., R.P. Kwok, N. Lamb, M. Hagiwara, M.R. Montminy, and R.H. Goodman. 1993. Phosphorylated CREB binds specifically to the nuclear protein CBP. Nature 365: 855-859.

Constantinou-Deltas, C.D., J. Gilbert, R.J. Bartlett, M. Herbstreith, A.D. Roses, and J.E. Lee. 1992. The identification and characterization of KRAB-domain-containing zinc finger proteins. Genomics 12: 581-589.

Cooper, J.P., S.Y. Roth, and R.T. Simpson. 1994. The global transcriptional regulators, SSN6 and TUP1, play distinct roles in the establishment of a repressive chromatin structure. Genes \& Dev. 8: 1400-1410.

Crew, A.J., J. Clark, C. Fisher, S. Gill, R. Grimer, A. Chand, J. Shipley, B.A. Gusterson, and C.S. Cooper. 1995. Fusion of SYT to two genes, SSX1 and SSX2, encoding proteins with homology to the Kruppel-associated box in human synovial sarcoma. EMBO I. 14: 2333-2340.

Eckner, R., M.E. Ewen, D. Newsome, M. Gerdes, J.A. DeCaprio, J.B. Lawrence, and D.M. Livingston. 1994. Molecular cloning and functional analysis of the adenovirus E1A-associated $300-\mathrm{kD}$ protein $(\mathrm{p} 300)$ reveals a protein with properties of a transcriptional adaptor. Genes \& Dev. 8: 869-884.

Fisher, A.L., S. Ohsako, and M. Caudy. 1996. The WRPW motif of the hairy-related basic helix-loop-helix repressor proteins acts as a 4-amino-acid transcription repression and proteinprotein interaction domain. Mol. Cell. Biol. 16: 2670-2677.

Fondell, J.D., A.L. Roy, and R.G. Roeder. 1993. Unliganded thyroid hormone receptor inhibits formation of a functional preinitiation complex: Implications for active repression. Genes \& Dev. 7: 1400-1410.

Fondell, J.D., F. Brunel, K. Hisatake, R.G. Roeder, J.D. Fondell, A.L. Roy, and R.G. Roeder. 1996. Unliganded thyroid hormone receptor alpha can target TATA-binding protein for transcriptional repression. Mol. Cell. Biol. 16: 281-287.

Fredericks, W.J., N. Galili, S. Mukhopadhyay, G. Rovera, J. Bennicelli, F.G. Barr, and F.J. Rauscher III. 1995. The PAX3FKHR fusion protein created by the $t(2 ; 13)$ translocation in alveolar rhabdomyosarcomas is a more potent transcriptional activator than PAX3. Mol. Cell. Biol. 15: 1522-1535.

Freemont, P.S. 1993. The RING finger. A novel protein sequence motif related to the zinc finger. Ann. NY Acad. Sci. 684: 174-192.

Georgakopoulos, T. and G. Thireos. 1992. Two distinct yeast transcriptional activators require the function of the GCN5 protein to promote normal levels of transcription. EMBO /. 11: 4145-4152.

Gill, G. and M. Ptashne. 1988. Negative effect of the transcriptional activator GAL4. Nature 334: 721-724.
Goulding, M.D., G. Chalepakis, U. Deutsch, J.R. Erselius, and P. Gruss. 1991. Pax-3, a novel murine DNA binding protein expressed during early neurogenesis. EMBO $/$. 10: 11351147.

Guarente, L. 1995. Transcriptional coactivators in yeast and beyond. Trends Biochem. Sci. 20: 517-521.

Haynes, S.R., C. Dollard, F. Winston, S. Beck, J. Trowsdale, and I.B. Dawid. 1992. The bromodomain: A conserved sequence found in human, Drosophila and yeast proteins. Nucleic Acids Res. 20: 2603.

Horlein, A.J., A.M. Naar, T. Heinzel, J. Torchia, B. Gloss, R. Kurokawa, A. Ryan, Y. Kamei, M. Soderstrom, C.K. Glass, and M.G. Rosenfeld. 1995. Ligand-independent repression by the thyroid hormone receptor mediated by a nuclear receptor co-repressor. Nature 377: 397-404.

Kakizuka, A., W.H. Miller Jr., K. Umesono, R.P. Warrell Jr., S.R. Frankel, V.V. Murty, E. Dmitrovsky, and R.M. Evans. 1991. Chromosomal translocation $\mathrm{t}(15 ; 17)$ in human acute promyelocytic leukemia fuses RAR alpha with a novel putative transcription factor, PML. Cell 66: 663-674.

Keleher, C.A., M.J. Redd, J. Schultz, M. Carlson, and A.D. Johnson. 1992. Ssn6-Tupl is a general repressor of transcription in yeast. Cell 68: 709-719.

Kelley, R.L., I. Solovyeva, L.M. Lyman, R. Richman, V. Solovyev, and M.I. Kuroda. 1995. Expression of msl-2 causes assembly of dosage compensation regulators on the $\mathrm{X}$ chromosomes and female lethality in Drosophila. Cell 81: 867877.

Klug, A. and J.W. Schwabe. 1995. Protein motifs 5. Zinc fingers. FASEB I. 9: 597-604.

Kozak, M. 1992. Regulation of translation in eukaryotic systems. Annu. Rev. Cell Biol. 8: 197-225.

Laurent, B.C., M.A. Treitel, and M. Carlson. 1991. Functional interdependence of the yeast SNF2, SNF5, and SNF6 proteins in transcriptional activation. Proc. Natl. Acad. Sci. 88: 2687-2691.

LeDouarin, B., C. Zechel, J.M. Garnier, Y. Lutz, L. Tora, P. Pierrat, D. Heery, H. Gronemeyer, P. Chambon, and R. Losson. 1995. The N-terminal part of TIF1, a putative mediator of the ligand-dependent activation function (AF-2) of nuclear receptors, is fused to B-raf in the oncogenic protein T18. EMBO I. 14: 2020-2033.

Lupas, A., M. Van Dyke, and J. Stock. 1991. Predicting coiled coils from protein sequences. Science. 252: 1162-1164.

Madden, S.L., D.M. Cook, J.F. Morris, A. Gashler, V.P. Sukhatme, and F.J. Rauscher III. 1991. Transcriptional repression mediated by the WT1 Wilms tumor gene product. Science 253: 1550-1553.

Madden, S.L., D.M. Cook, and F.J. Rauscher III. 1993. A structure-function analysis of transcriptional repression mediated by the WT1, Wilms tumor suppressor protein. Oncogene 8: 1713-1720.

Margolin, J.F., J.R. Friedman, W.K. Meyer, H. Vissing, H.J. Theisen, and F.J. Rauscher III. 1994. Kruppel-associated boxes are potent transcriptional repression domains. Proc. Natl. Acad. Sci. 91: 4509-4513.

Miki, T., T.P. Fleming, M. Crescenzi, C.J. Molloy, S.B. Blam, S.H. Reynolds, and S.A. Aaronson. 1991. Development of a highly efficient expression cDNA cloning system: Application to oncogene isolation. Proc. Natl. Acad. Sci. 88: 51675171.

Miki, Y., J. Swensen, D. Shattuck-Eidens, P.A. Futreal, K Harshman, S. Tavtigian, Q. Liu, C. Cochran, L.M. Bennett, W. Ding, R. Bell, J. Rosenthal, C. Hussey, T. Tran, M. McClure, C. Frye, T. Hattier, R. Phelps, A. Haugen-Strano, H. Katcher, K. Yakumo, Z. Gholami, D. Shaffer, S. Stone, S. 
Bayer, C. Wray, R. Bogden, P. Dayananth, J. Ward, P. Tonin, S. Narod, P.K. Bristown, F.H. Norris, L. Helvering, P. Morrison, P. Rosteck, M. Lai, C. Barrett, C.Lewis, S. Neuhausen, L. Cannon-Albright, D. Goldgar, R. Wiseman, A. Kamb, and M.H. Skolnick. 1994. A strong candidate for the breast and ovarian cancer susceptibility gene BRCA1. Science 266: 6671.

Morris, J.F., S.L. Madden, O.E. Tournay, D.M. Cook, V.P. Sukhatme, and F.J. Rauscher III. 1991. Characterization of the zinc finger protein encoded by the WT1 Wilms tumor locus. Oncogene 6: 2339-2348.

Paroush, Z., R.L. Finley Jr., T. Kidd, S.M. Wainwright, P.W. Ingham, R. Brent, and D. Ish-Horowicz. 1994. Groucho is required for Drosophila neurogenesis, segmentation, and sex determination and interacts directly with hairy-related bHLH proteins. Cell 79: 805-815.

Pengue, G., A. Caputo, C. Rossi, G. Barbanti-Brodano, and L. Lania. 1995. Transcriptional silencing of human immunodeficiency virus type 1 long terminal repeat-driven gene expression by the Kruppel-associated box repressor domain targeted to the transactivating response element. I. Virol. 69: 6577-6580.

Sadowski, I., B. Bell, P. Broad, and M. Hollis. 1992. GAL4 fusion vectors for expression in yeast or mammalian cells. Gene 118: $137-141$.

Sauer, F., J.D. Fondell, Y. Ohkuma, R.G. Roeder, and H. Jackle. 1995. Control of transcription by Kruppel through interactions with TFIIB and TFIIE beta. Nature 375: 162-164.

Schreiber-Agus, N., L. Chin, K. Chen, R. Torres, G. Rao, P. Guida, A.I. Skoultchi, and R.A. DePinho. 1995. An aminoterminal domain of Mxil mediates anti-Myc oncogenic activity and interacts with a homolog of the yeast transcriptional repressor SIN3. Cell 80: 777-786.

Shi, Y., E. Seto, L.S. Chang, and T. Shenk. 1991. Transcriptional repression by YY1, a human GLI-Kr8l ppel-related protein, and relief of repression by adenovirus ElA protein. Cell 67: 377-388.

Thiesen, H.J., E. Bellefroid, O. Revelant, and J.A. Martial. 1991. Conserved KRAB protein domain identified upstream from the zinc finger region of Kox 8. Nucleic Acids Res. 19: 3996.

Tjian, R. and T. Maniatis. 1994. Transcriptional activation: A complex puzzle with few easy pieces. Cell 77: 5-8.

Tommerup, N., L. Aagaard, C.L. Lund, E. Boel, S. Baxendale, G.P. Bates, H. Lehrach, and H. Vissing. 1993. A zinc-finger gene ZNF141 mapping at pl6.3/D4S90 is a candidate gene for the Wolf-Hirschhorn (4p-) syndrome. Hum. Mol. Gen. 2: $1571-1575$.

Tzamarias, D. and K. Struhl. 1994. Functional dissection of the yeast Cyc8-Tupl transcriptional co-repressor complex. $\mathrm{Na}$ ture 369: 758-761.

Um, M., C. Li, and I.L. Manley. 1995. The transcriptional repressor even-skipped interacts directly with TATA-binding protein. Mol. Cell. Biol. 15: 5007-5016.

Vissing, H., W.K. Meyer, L. Aagaard, N. Tommerup, and H.J. Thiesen. 1995. Repression of transcriptional activity by heterologous $\mathrm{KRAB}$ domains present in zinc finger proteins. FEBS Lett. 369: 153-157.

Witzgall, R., E. O'Leary, R. Gessner, A.J. Ouellette, and J.V. Bonventre. 1993. Kid-1, a putative renal transcription factor: Regulation during ontogeny and in response to ischemia and toxic injury. Mol. Cell. Biol. 13: 1933-1942.

Witzgall, R., R. Volk, R.S. Yeung, and J.V. Bonventre. 1994. Genomic structure and chromosomal location of the rat gene encoding the zinc finger transcription factor kid-1. Genomics 20: 203-209.

Yew, P.R., X. Liu, and A.J. Berk. 1994. Adenovirus E1B onco- protein tethers a transcriptional repression domain to $\mathrm{p} 53$. Genes \& Dev. 8: 190-202.

Yoshimoto, H. and I. Yamashita. 1991. The GAM1/SNF2 gene of Saccharomyces cerevisiae encodes a highly charged nuclear protein required for transcription of the STAl gene. Mol. Gen. Genet. 228: 270-280.

Zawel, L. and D. Reinberg. 1995. Common themes in assembly and function of eukaryotic transcription complexes. Annu. Rev. Biochem. 64: 533-561.

Zhou, S., Y. Yang, M.J. Scott, A. Pannuti, K.C. Fehr, A. Eisen, E.V. Koonin, D.L. Fouts, R. Wrightsman, J.E. Manning, and J.C. Lucchesi. 1995. Male-specific lethal 2, a dosage compensation gene of Drosophila, undergoes sex-specific regulation and encodes a protein with a RING finger and a metallothionein-like cysteine cluster. $E M B O F$. 14: 2884-2895. 


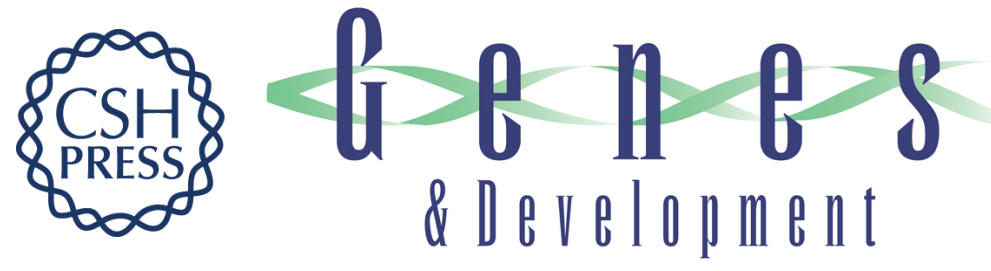

\section{KAP-1, a novel corepressor for the highly conserved KRAB repression domain.}

J R Friedman, W J Fredericks, D E Jensen, et al.

Genes Dev. 1996, 10:

Access the most recent version at doi:10.1101/gad.10.16.2067

References This article cites 60 articles, 20 of which can be accessed free at:

http://genesdev.cshlp.org/content/10/16/2067.full.html\#ref-list-1

License

Email Alerting

Service

Receive free email alerts when new articles cite this article - sign up in the box at the top right corner of the article or click here.

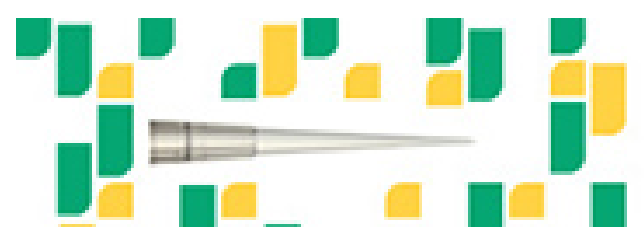

Focused on your science.

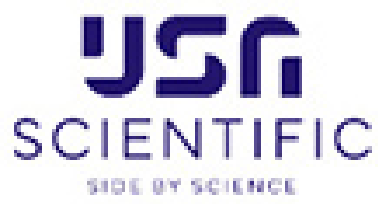

Copyright @ Cold Spring Harbor Laboratory Press 